\title{
PENGARUH TRADISI TABOB TERHADAP PENYU BELIMBING DI KEPULAUAN KEI, MALUKU TENGGARA
}

\author{
Aditano Yani Retawimbi \\ Program Magister Manajemen Sumberdaya Pantai Universitas Diponegoro \\ email: adit_undip@yahoo.com; cp. 081325087380
}

\begin{abstract}
One of the traditions of the society of Nu Fit The Kei, Southeast Maluku, which is Tabob to perform a ritual to hunt and consume the meat of the species of leatherbacks Dermochelys coriacea (leatherback turtle). More recently, the tradition of tabob examined became one of the causes of the declining population of leatherbacks, so this turtle species need protection to keep it from extinction. In this article in question is, does the ritual of tabob significantly affect a decrease in the number of population of leatherbacks.
\end{abstract}

Key words: tradition, leatherback turtle, tabob, Southeast Maluku

\section{Pendahuluan}

Kehidupan sosial budaya masyarakat pesisir dan pulau di Indonesia sangatlah beragam, yang secara langsung dan tidak langsung dipengaruhi oleh faktor alam di sekitarnya. Perilaku sosial budaya berkaitan erat dengan perilaku masyarakat dalam memanfaatkan sumberdaya alam di sekitarnya. Salah satu perilaku sosial budaya yang dilaksanakan oleh masyarakat Nufit Kepulauan Kei, Maluku Tenggara adalah tradisi Tabob, yaitu ritual untuk melakukan perburuan dan mengkonsumsi daging dari spesies penyu belimbing (Dermochelys coriacea) yang sudah dilakukan sejak turun-temurun dan menjadi tradisi budaya masyarakat di Kepulauan Kei.

Berdasarkan penelitian yang dilakukan World Wildlife Foundation (WWF), sejak 1984 hingga 1999 populasi penyu belimbing telah menurun dari 13.000 sarang pada tahun 1984 menjadi 2.983 sarang pada tahun 1999 (WWF, 2010, dalam http://www.wwf.or.id 2010. Penyu Belimbing). Berdasarkan konvensi CITES (Convention on International Trade of Endangered Species of Wild Fauna and Flora) penyu dimasukkan ke dalam appendiks 1 dan ditegaskan dalam Peraturan Pemerintah Nomor 7 tahun 1999 (Nurapriyanto, 2003) bahwa penyu terancam punah dan tidak boleh diperdagangkan secara bebas. Hal ini menunjukkan bahwa kondisi spesies penyu perlu mendapatkan perlindungan yang komprehensif dan intensif secara terpadu.

Salah satu pemicu menurunnya populasi penyu belimbing adalah budaya perburuan tradisional yang dilakukan oleh masyarakat pesisir, sehingga salah satu cara untuk menanggulangi permasalahan tersebut harus dilakukan pengelolaan dan penyuluhan kepada masyarakat khususnya masyarakat kepulauan Kei Maluku Tenggara agar populasi penyu belimbing tersebut tidak menurun secara terusmenerus setiap tahun.

Permasalahan yang utama adalah menurunnya jumlah populasi Penyu belimbing (Dermochelys coriacea) yang dikaitkan dengan ritual perburuan penyu yang disebut Tabob, sehingga menjadi pertanyaan adalah, apakah ritual tersebut secara signifikan berpengaruh atau tidak, terhadap penurunan jumlah populasi penyu belimbing. 


\section{Tradisi Perburuan Tabob}

Tabob (sebutan dalam bahasa Kei,) atau dalam bahasa Indonesia disebut penyu belimbing, merupakan salah satu sumberdaya laut yang khas dan endemik di kawasan pesisir barat Pulau Kei Kecil, khususnya di kawasan masyarakat adat $\mathrm{Nu}$ Fit Roah, karena jalur migrasi mereka yang melewati kepulauan Kei untuk menuju ke Papua, atau sebaliknya. Pandangan tentang ketersediaan Sumber Daya Laut (SDL) oleh masyarakat di Nu Fit Roah adalah bahwa Tabob tidak menyebabkan kepunahan penyu belimbing. $\mathrm{Hal}$ ini berdasarkan anggapan masyarakat tradisional bahwa Tabob sebagai Tad (tanda), Ub (leluhur), dan makanan pusaka mereka. Ini membuat mereka dapat berburu Tabob sebanyak mungkin tanpa memperhatikan kelestariannya (www. Maluku Tenggara kab.go.id, 2010).

Beberapa kajian, penelitian dan pendekatan yang telah dilakukan oleh tim SIRAN, lembaga swadaya masyarakat lokal yang peduli pada satwa ini, di antaranya pada tahun-tahun 2004, 2006, 2007, 2009, menunjukkan bahwa tingkat perburuan Tabob untuk keperluan konsumsi saat ini sudah mulai berkurang. Hal ini dikarenakan jumlah penduduk yang semakin tinggi dan jumlah Tabob di alam semakin berkurang sehingga memicu kesadaran masyarakat setempat akan pentingnya peran Tabob bagi mereka (www.Tabob-evav.co.cc., 2010).

Diperkirakan kalau tidak ada tindakan pencegahan dalam bentuk konservasi maupun perlindungan lainnya yang dilakukan oleh pemerintah dan instansi terkait dan dibantu dengan pemahaman serta informasi tentang Tabob, maka mungkin saja pada tahun-tahun mendatang Tabob akan punah. Masyarakat di $\mathrm{Nu}$ fit meyakini bahwa Tabob yang ada di perairan Nu Fit berasal dari laut Papua. Tabob akan datang di perairan Nu Fit dalam jumlah yang banyak ketika musim barat tiba (ditandai dengan bunyi guntur di utara, pada bulan September-Pebruari); selain itu Tabob bisa "disuruh atau diperintah" berbalik, angkat kepala dan lainnya ketika mau ditikam, serta sangat jinak walau didekati dengan perahu. Tabob merupakan Tom-Tad (artinya tanda) bagi orang Nu Fit dan merupakan makanan pusaka dan tidak

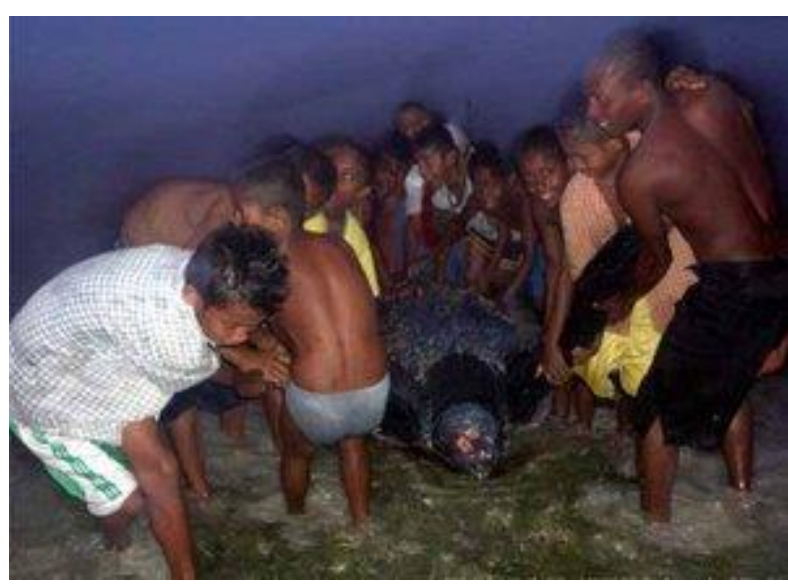

Gambar 1. Tradisi Perburuan Tabob

(Dermochelys coriacea)(Sumber: http:// www.gilnova.multiply.com)

akan pernah punah. Tujuh garis yang terdapat pada punggung Tabob adalah lambang milik orang Nu Fit. Tabob yang berkepala putih adalah tabob yang paling besar (www. Maluku Tenggara kab.go.id, 2010).

\section{Ritual Tabob}

Ritual perburuan Tabob dilakukan antara bulan Agustus sampai Februari, dan penyu belimbing ditangkap untuk kebutuhan konsumsi masyarakat sepanjang musim itu, masyarakat bisa mendapat 20 hingga 30 penyu belimbing, dengan keyakinan bahwa penyu jenis Tabob ini adalah makanan pusaka dari leluhurnya. Sebelum aktivitas berburu dilakukan, serangkaian ritual adat harus dipenuhi. Sebelum perburuan dilakukan, terlebih dulu masyarakat yang akan turun ke laut meminta ijin dari tetua adat yang bergelar Reyaan Hemas di desa Ohidertutu (www.gilnova.multiply.com, 2010). 

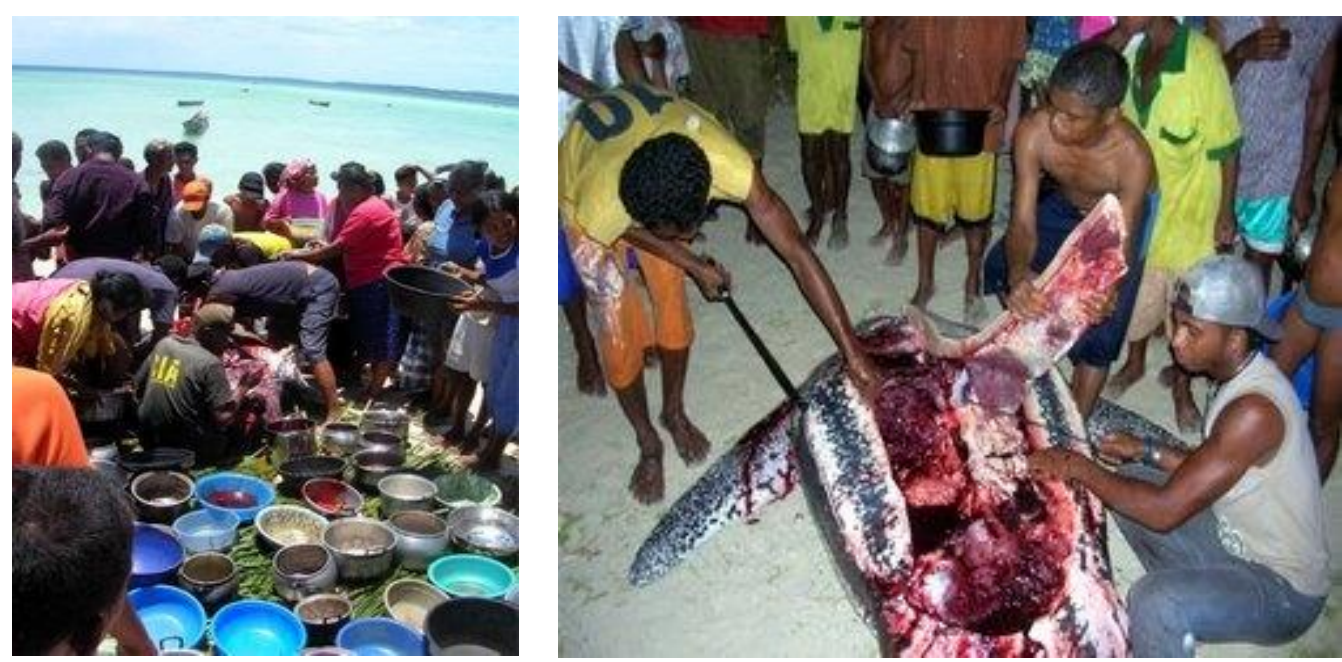

Gambar 2. Ritual Tabob oleh Masyarakat Nufit Kepulauan Kei

(Sumber: http:// www.gilnova.multiply.com).

Dari pembagian peran $\begin{array}{r}\text { adat, } \\ \text { Remas }\end{array}$
pemangku
bertanggungjawab langsung dengan penyu
belimbing dan mengatur pola penangkapannya. Sebelumnya ada juga tradisi angkat siri-pinang dan baca doa adat. Para pemburu Tabob juga dibatasi dengan sejumlah larangan, seperti menggunakan aksesoris rantai atau gelang berbahan logam selama perburuan; dilarang memakai topi, dan laki-laki yang istrinya sedang hamil dilarang ikut berburu; selain itu, orang di luar komunitas Nufit juga dilarang ikut berburu.

Dalam tradisi masyarakat Nufit, daging dari hasil tangkapan penyu belimbing harus dibagi ke setiap anggota masyarakat adat setempat. Bahkan perempuan yang tengah mengandung diberi dua bagian daging karena bayi di dalam kandungannya juga berhak mendapat jatah makanan pusaka ini (www.gilnova.multiply.com, 2010).

\section{Penyu Belimbing}

Penyu belimbing (Dermochelys coriacea) merupakan anggota Famili
Dermochelidae, Marga Dermochelys dengan nama jenis Dermochelys coriacea. Penyu belimbing merupakan jenis penyu yang paling mudah dikenali oleh masyarakat. Hal ini disebabkan oleh keadaan morfologi tubuh yang berukuran paling besar dibandingkan penyu yang lain (seperti Chelonia mydas dan Eretmochelys imbricata) ( Suktojo, 1997).

Penyu belimbing mempunyai punggung yang diliputi kulit kuat dari zat tanduk yang disebut karapas. Karapas penyu ini tidak bersisik, tetapi ada lima sampai tujuh garis tebal yang memanjang dari leher sampai ekor. Panjang karapas mencapai 2,5 $\mathrm{m}$ dengan berat mencapai $1500 \mathrm{Kg}$, umurnya dapat mencapai 200 tahun atau lebih. Musim kawinn penyu ini berlangsung dari bulan Juni sampai Agustus, betinanya mendarat untuk meletakkan telur-telurnya di pasir hingga mencapai 80 butir. Penyu ini menggali pasir kira-kira $50 \mathrm{~cm}$ dalamnya dengan diameter $50 \mathrm{~cm}$. Kemudian mereka bertelur dalam lubang dan menimbunnya kembali dengan pasir. Kegiatan ini dilakukan kira-kira selama $2 \frac{1}{2}$ jam. 


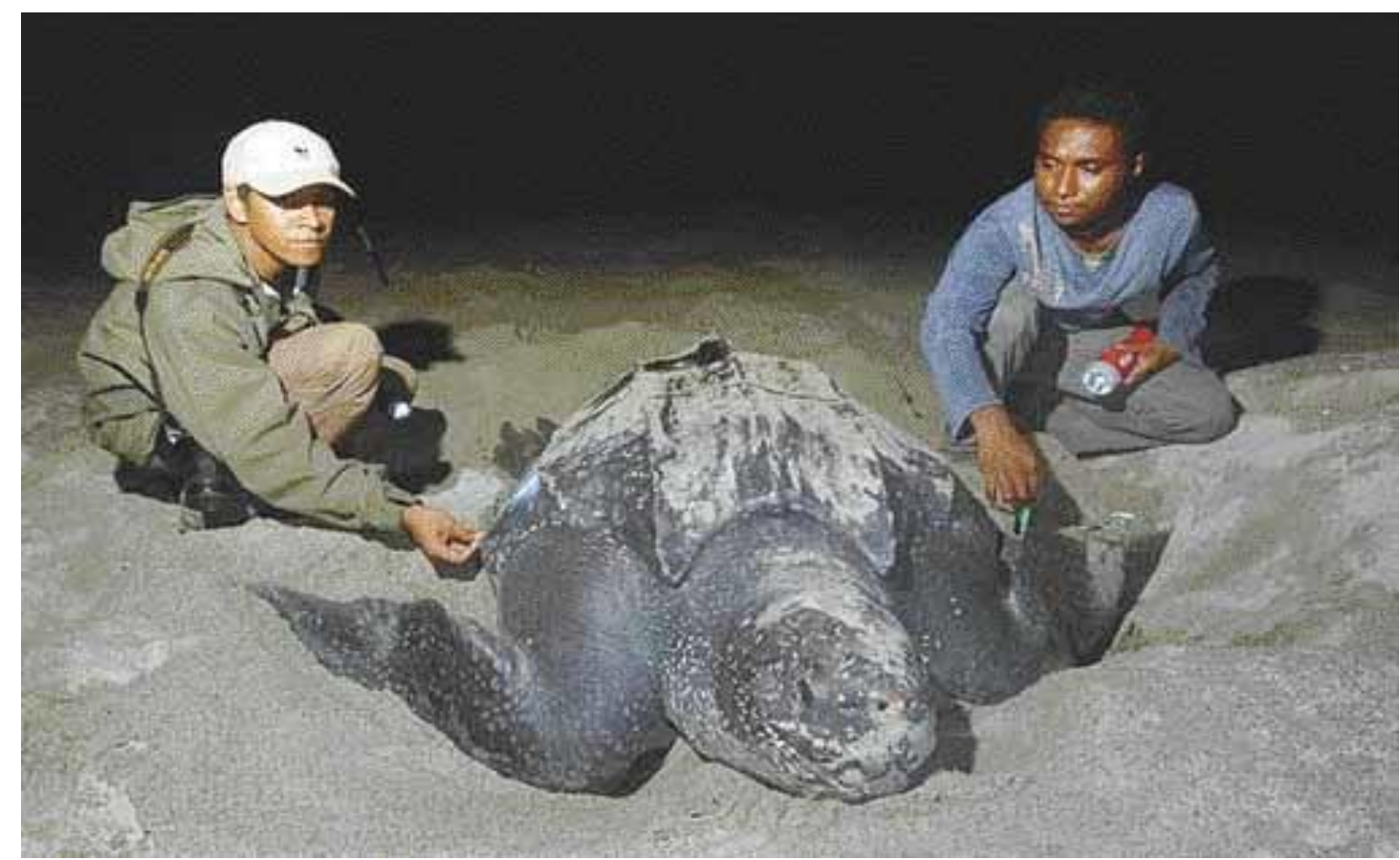

Gambar 3. Penyu Blimbing (Dermochelys coriacea)

(Sumber: http://www.cccturtle.org/leather.htm)

Pasir itu kemudian mengerami sendiri telur-telur itu selama 6-8 minggu sampai menetas menjadi tukik yang keluar dari sarang untuk kemudian merangkak ke laut (Romimohtarto, 1999).Bentuk kepala dari penyu belimbing relatif kecil, bulat dan tanpa ada sisik-sisik seperti halnya penyu yang lain. Penyu blimbing berukuran sekitar lebar $17 \%$ sampai $22,3 \%$ dari seluruh panjang karapas; mempunyai paruh yang lemah, tetapi berbentuk tajam, tidak punya permukaan penghancur atau pelumat makanan. Bentuk tubuh penyu jantan dewasa lebih pipih dibandingkan penyu betina, plastron mempunyai cekungan ke dalam, pinggul menyempit dan corseletnya tidak sedalam pada penyu betina. Warna karapas penyu dewasa kehitam-hitaman atau coklat tua, sedangkan di bagian atas dengan bercak-bercak putih dan di bagian bawah putih dengan bercak hitam (Prihanta, 2007).

Berat penyu ini dapat mencapai 1 ton dengan panjang dari ujung ekor sampai moncongnya lebih dari $215 \mathrm{~cm}$, sementara jenis penyu yang lainnya sekitar $100 \mathrm{~cm}$. Romimohtarto (1999) telah menghitung berat rata-rata penyu belimbing sekitar 300600 kg, bahkan ada yang mencapai 1500 $\mathrm{kg}$, dengan panjang tubuh sampai $2,5 \mathrm{~m}$. Penyu belimbing telah bertahan hidup selama lebih dari ratusan juta tahun, kini spesies ini menghadapi kepunahan.

Selama dua puluh tahun terakhir jumlah spesies ini menurun dengan cepat, khususnya di kawasan pasifik, hanya sekitar 2.300 betina dewasa yang tersisa.

Penyu belimbing dikenal oleh beberapa masyarakat dengan sebutan penyu raksasa, kantong atau mabo. Daerah peneluran penyu belimbing dapat ditemukan di pantai barat Sumatera, selatan Jawa, dan daerah tertutup di Nusa Tenggara (Dahuri, 2003). Disebutkan pula bahwa lokasi peneluran penyu belimbing terbesar di Indonesia terletak di Pantai Jamursba Medi, Sorong Irian Jaya, yang merupakan pantai peneluran penyu belimbing terbesar ketiga di kawasan IndoPasifik (Agus Dermawan, kom.Pribadi, 2002; dalam Dahuri, 2003).

Penyu ini dilindungi sejak tahun 1987 berdasarkan keputusan Menteri Pertanian no. $327 / \mathrm{Kpts} / \mathrm{Um} / 5 / 1978$. Hal ini menempatkan penyu belimbing Pasifik menjadi penyu laut yang paling terancam 
populasinya di dunia. Di kawasan Pasifik, seperti di Indonesia, populasinya hanya tersisa sedikit dari sebelumnya (2.983 sarang pada 1999 dari 13.000 sarang pada tahun 1984). Untuk mengatasi hal tersebut, pada tanggal 28 Agustus 2006 tiga negara yaitu Indonesia, Papua New Guinea dan Kepulauan Solomon, telah sepakat untuk melindungi habitat penyu belimbing melalui kesepakatan (MoU) Tri National Partnership Agreement (WWF, 2008). Taksonomi dari dari penyu belimbing yaitu Kingdom: Animalia; Phylum: Chordata; Class: Sauropsida; Order: Testudines; Suborder: Cryptodira; Superfamily: Chelonioidea; Family: Dermochelyidae; Spesies: Dermochelys coriacea.

\section{Ancaman terhadap Kehidupan Penyu}

Berbagai ancaman terhadap penyu dapat terjadi dalam bentuk sebagai berikut:

\subsection{Ancaman Kepunahan}

1) Pemangsaan Telur. Telur yang ditanam di dalam pasir merupakan tempat berlindung yang sangat penting. Sebelum menetas, telur-telur penyu seringkali tergali oleh induk penyu lainnya. Kepiting, tikus, biawak, dan hewan darat lainnya yang sering berada di pantai sangat suka memangsa telur penyu dan merupakan masa sulit bagi telur-telur tersebut. Telur yang lolos dari pemangsaan (biasanya kurang dari $100 \%$ ) akan menetas dan menjadi bayi penyu (WWF, 2008).

2) Ancaman terhadap Anak (tukik). Ketika telur menetas, muncullah bayi penyu yang kemudian berkembang menjadi anak penyu (tukik), kemudian merayap menuju dan berenang di laut, sementara itu burung elang dari ketinggian sudah mengincarnya. Selain itu, ketika sampai pada bibir pantai, ikan-ikan pelagis besar dapat memangsa penyu tersebut untuk tujuan yang sama, sebagai makanan bagi mereka. Anak penyu yang selamat akan berenang dan memulai hidup mereka di laut seperti layaknya ikan (WWF, 2008).

3) Ancaman terhadap Penyu Dewasa. Walaupun sudah menjadi penyu dewasa, masih saja terdapat ancaman pemangsaan lainnya, seperti dimangsa oleh hiu, paus dan ikan yang lebih besar ukurannya.

4) Ancaman Wabah Penyakit. Wabah penyakit bisa saja membunuh penyu beserta habitatnya secara menyeluruh. Hal ini kemungkinan disebabkan oleh pencemaran di kawasan tersebut yang manghasilkan bakteri atau virus yang mampu menembusi daya ketahanan badan penyu di kawasan tersebut. Selain itu, air laut yang telah tercemar juga dapat membunuh penyu maupun biota laut lainnya.

5) Ancaman Abrasi. Abrasi dapat mengurangi lokasi peneluran bagi penyu. Oleh karena pantai merupakan tempat untuk penyu menetaskan telur-telurnya, maka kehilangan pantai akibat abrasi akan mengancam regenerasi penyu yang akan datang.

6) Perubahan Cuaca dan Musim. Suhu dan musim merupakan faktor penentu penetasan telur penyu oleh induk betinanya. Oleh karena itu, perubahan suhu dan musim sangat mempengaruhi jumlah telur yang berhasil menetas dan sel kelamin yang dihasilkan. Suhu pengeraman yang melebihi $29{ }^{\circ} \mathrm{C}$ akan menghasilkan lebih banyak anak penyu betina; sedangkan suhu yang kurang dari $29{ }^{\circ} \mathrm{C}$ akan menghasilkan lebih banyak anak penyu jantan. Ketidak-seimbangan jumlah antara penyu jantan dan penyu betina akan mengancam kewujudan penyu yang hanya matang pada kurun waktu 20 sampai 30 tahun (WWF, 2008).

\subsection{Ancaman Lain}

Selain ancaman alami, adapula ancaman lain yang berasal dari aktivitas manusia, seperti sebagai berikut: 1) pengambilan telur di pantai peneluran oleh 
manusia; 2) pembangunan fasilitas tertentu di lokasi peneluran; 3) eksploitasi berlebihan untuk dimakan atau sebagai umpan hiu; 4) aktivitas perikanan, seperti jaring hiu dan trawl; 5) pemasaran terbuka terhadap beberapa jenis penyu (Romimohtarto, 1999).

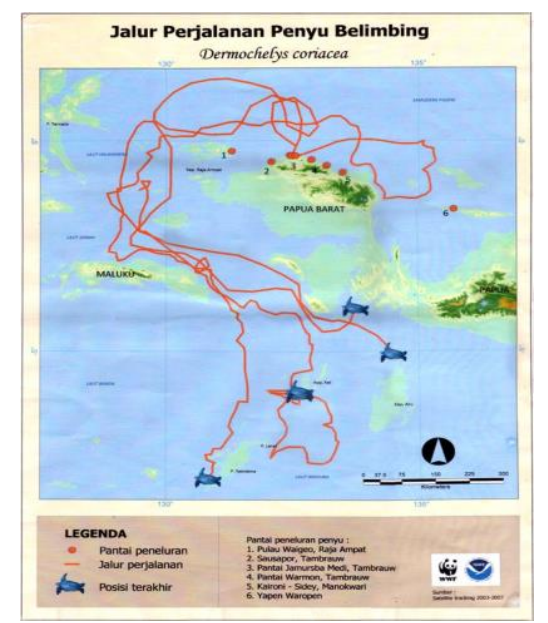

Gambar 4. Peta Jalur Perjalan Penyu Belimbing di Wilayah Timur Indonesia (Sumber: WWF, 2008)

\section{Penutup}

Berbagai macam budaya tradisional pesisir Indonesia patut dilestarikan sebagai sumber kebhinekaan bangsa Indonesia. Tetapi apabila suatu tradisi budaya tersebut sudah mulai mengganggu atau mengancam keberadaan sumberdaya lain ada baiknya tradisi tersebut dimodifikasi atau dialihkan menjadi sesuatu hal lain yang tidak mengganggu keseimbangan ekosistem sumberdaya di pesisir. Hal ini bisa kita kaitkan dengan upacara Tabob yang selalu dilaksanakan secara turun temurun oleh masyarakat Nu Fit Roa di Kepulauan Kei. Apabila tradisi budaya Tabob terusmenerus dilakukan maka dapat dipastikan penyu belimbing yang habitat migrasinya melewati kepulauan Kei akan cepat punah dan hal tersebut secara signifikan dapat mengancam keberadaan populasi penyu belimbing secara global. Tetapi apabila tradisi budaya tersebut dibatasi dan mungkin dimodifikasi menjadi suatu tradisi baru dapat dipastikan populasi penyu Belimbing sedikit demi sedikit akan kembali meningkat. Hal ini didasarkan pada fakta bahwa salah satu spesies langka yang terancam punah adalah penyu Belimbing dan kita harus melindunginya untuk menjaga kelestariannya.

Harus disadari bahwa selain adanya upacara Tabob, seiring dengan bertambahnya jumlah manusia, penyu juga akan mengalami berbagai kesulitan. Banyak manusia yang seringkali merusak habitat tempat penyu bertelur. Manusia juga memburu telur-telur penyu dan penyupenyu dewasa sehingga menurunkan tingkat pertumbuhan populasi penyu. Hal tersebut semakin diperparah dengan adanya polusi yang disebabkan oleh ulah manusia berupa tumpahan minyak dari pengeboran minyak di lepas pantai dan plastik yang menyebabkan rusaknya ekosistem, termasuk juga ekosistem pantai tempat habitat dan tempat bertelur penyu.

Beberapa upaya telah dilakukan di seluruh Indonesia untuk melestarikan berbagai macam penyu yang terancam kelestariannya, termasuk penyu belimbing. Salah satunya adalah dengan pengelolaan kelestarian penyu yang berkelanjutan, melalui penangkaran penyu. Penangkaran penyu yang ada di Indonesia antara lain penangkaran penyu sisik di Pulau Pramuka, penangkaran penyu sisik di Balai Taman Nasional Laut Kepulauan Seribu (TNLKpS), program penyelamatan penyu di Kuta, dan penangkaran penyu Sukamaju di Pekon Muara Tembulih.

Masalah pengelolaan penyu juga menyangkut berbagai macam kepentingan yang melibatkan berbagai instansi dan lembaga, baik pemerintah maupun swasta dan masyarakat. Oleh karena itu dalam melaksanakan pengelolaan penyu laut perlu adanya koordinasi antara instansi terkait sehingga tidak terjadi pengelolaan yang tumpang tindih dan terhindarnya produk hukum yang berbeda tentang pengelolaan sumber daya penyu.

Selain itu, pemberian penyuluhan dan tindakan peringatan kepada masyarakat bahwa sumberdaya penyu belimbing adalah salah satu spesies yang terancam punah populasinya dan patut dilindungi. Dengan penyuluhan dan pengelolaan ini, 
diharapkan masyarakat pesisir akan mulai mengurangi dan membatasi tradisi budaya Tabob dan akan lebih peduli terhadap penyu yang sudah terancam kelestariannya.

\section{Daftar Pustaka}

Dahuri, R. 2003. Keanekaragaman Hayati Laut. Jakarta: Gramedia Pustaka Utama.

Nurapriyanto. 2003. "Perburuan Penyu di Kawasan Taman Nasional Teluk Cendrawasih." Penelitian Hutan no.640, hal. 18-25.

Prihanta, Wahyu. 2007. "Problematika kegiatan konservasi penyu di taman nasional Meru Betiri." Laporan Penelitian Pengembangan IPTEK. Fakultas Keguruan dan IImu Pendidikan Universitas Muhammadiyah Malang.

Romimohtarto, $\mathrm{K}$ dan Sri Juwana. 1999. Biologi Laut. Jakarta: Puslitbang Oseanologi-LIPI.

Sukotjo, A.S. 1997. "Pemanfaatan Penyu di Indonesia." Makalah Workshop Penelitian dan Pengelolaan Penyu Indonesia, Direktorat Jenderal Perlindungan Hutan dan Pelestarian Alam, Bogor.

\section{Sumber Web Internet}

http://www.cccturtle.org/leather.htm Diunduh pada tanggal 15 Juni 2011 pukul 22.15 WIB.

http://www.gilnova.multiply.com, 2010. Perburuan Penyu Belimbing Di perairan Kei. Diunduh Pada tanggal 16 Juni 2011 pukul 16.10 WIB.

http://www

MalukuTenggarakab.go.id, 2010. Tabob Di Nu Fit Roa. Diunduh pada tanggal 17 Juni 2011 pukul 22.15 WIB.

http://www. Tabob-evav.co.cc. 2010.Sejarah Tabob. Diunduh pada tanggal 15 Juni 2011 pukul 11.15 WIB. http://www.wwf.or.id

2008.Pemantauan Penyu dengan Satelit. Diunduh pada tanggal 17 Juni 2011 pukul 22.20 WIB.

WWF, 2008; WWF, 2010. http://www.wwf.or.id 2010. Penyu Belimbing (Leatherback Turtle). Diunduh pada tanggal 17 Juni 2011 pukul 22.10 WIB. 